\title{
11
}

\section{External Donors and Social Protection in Africa: A Case Study of Zimbabwe}

\author{
Stephen Devereux and Samuel Kapingidza
}

\section{Introduction}

More than half the countries in Africa have adopted social protection as a policy instrument since the late 1990s. External actors have been instrumental in this rapid diffusion of social protection policies and programs across the continent. These external actors, also called "transnational actors", "development partners" or the "international development community", include bilateral donors (e.g. the UK Department for International Development [DFID], Irish Aid), multilateral agencies (e.g. the European Union [EU]), United Nations (UN) agencies (e.g. the International Labour Organization [ILO], United Nations Children's Fund [UNICEF]), international financial institutions (IFIs) (e.g. the

\section{S. Devereux $(\bowtie)$}

Institute of Development Studies, University of Sussex, Brighton, UK e-mail: s.devereux@ids.ac.uk

S. Kapingidza

Centre for Social Development in Africa (CSDA), University of Johannesburg, Johannesburg, South Africa 
World Bank) and international non-governmental organizations (INGOs) (e.g. Concern Worldwide, Save the Children).

The success of this policy diffusion process can be observed in the rapidly increasing number of social protection programs implemented and national strategies drafted in numerous African countries. Rather than emerging from the domestic political discourse, however, typically these programs and strategies have been introduced by external actors, using a combination of "carrots" (financial assistance and technical support) and "sticks" (conditionality on loans, or threats to withhold aid). This naturally raises questions about whether a social protection policy process reflects the priorities of domestic (national) or external (transnational) actors.

External actors have greatest potential to dominate a policy process in countries that are politically weak and financially constrained. The promise of free or concessional external funding to boost domestic spending on social programs gives development partners "soft power" to decide how their funds will be spent, often relegating the government to a passive recipient. This power asymmetry explains why many of Africa's poorest countries have implemented almost identical social protection policies and cash transfer programs in recent years. Most of these policies and programs were designed by international consultants and financed by international development agencies, drawing on ideas generated and tested in other countries.

Zimbabwe is a case in point. The evolution of the flagship harmonised social cash transfer (HSCT) program was almost entirely donor-driven, from design to piloting to rolling out and then scaling down. Similarly, the development of the National Social Protection Policy Framework (NSPPF) was pushed by a range of UN agencies and bilateral donors, who disputed among themselves over which direction the policy should take, while the government was little more than a passive observer. Zimbabwe is selected as our case study because it has received less attention in this literature than comparable countries such as Zambia, where the influence of external actors is better documented (Kuss 2015; Pruce and Hickey 2017). Moreover, the case of Zimbabwe is atypical in that external actors managed to influence the social protection policy process despite the international isolation of the government of Zimbabwe. 
Sanctions imposed on the Mugabe regime by the EU and USA meant that major bilateral agencies would not fund the government directly, while outstanding arrears to IFIs meant that the government would not be bailed out. Instead, donors funded the social protection policy process through UNICEF. This is contrary to other African countries where donors funded the government directly to introduce or expand social protection. Finally though, Zimbabwe is unusual because, as we will show, the process of introducing social protection seems to have stalled, for reasons that have important lessons for analysts of social policy as well as for other African governments and international agencies.

This chapter first identifies several specific strategies that external actors have deployed to encourage or induce the introduction and expansion of social protection by African governments. Then the application of these strategies in Zimbabwe is reviewed, drawing on the insights and perceptions of external actors and national stakeholders who were directly involved in this policy process. Finally, we conclude by proposing a checklist of indicators that can be monitored to assess the extent to which a social protection policy process is "donor-driven" rather than "nationally owned".

\section{Strategies of External Actors}

In this section we discuss four strategies that are commonly used by external actors to persuade African governments to adopt social protection (see Devereux 2018): (1) building evidence: demonstrating the effectiveness of social protection through impact evaluations; (2) building capacity: strengthening the human resources and management systems for delivering social protection; (3) financial support: contributing toward the development and operational costs of social protection programs and (4) policy support: providing technical inputs to the process of developing social protection policies. 


\section{Building Evidence}

In the early 2000s donor agencies designed, financed and implemented social cash transfer (SCT) pilot projects at local level in several African countries, either alone or in collaboration with national governments and NGO partners. The primary objective was to improve the well-being of project beneficiaries — cash transfer recipients and their families. However, an equally important secondary objective was to persuade governments to implement cash transfer programs at national level. The implicit theory of change was that demonstrating the positive impacts of cash transfer projects would convince African governments to take over the management and financing of these projects, and scale them up to national coverage.

For this reason, external actors invested heavily in monitoring and evaluation (M\&E) of these pilot projects. One of the first was the Kalomo District Pilot Social Cash Transfer Scheme in Zambia, implemented by the Ministry of Community Development and Social Services (MCDSS) from 2003, with technical and financial support from German Technical Cooperation (GTZ). Monitoring of beneficiaries recorded positive changes in household food security, livestock ownership and other indicators after they joined the scheme (MCDSS and GTZ 2007).

In the mid-2000s several more pilot projects were launched by international NGOs with donor funding in southern Africa, usually running for one to two years and experimenting with different modalities—cash versus food, electronic payments, cash transfers in emergencies and so on. Examples include "Food and Cash Transfers" in Malawi, "Emergency Drought Response" in Swaziland and "Cash and Food Transfers Pilot Project" in Lesotho. All these projects were evaluated by independent researchers who were commissioned by the implementing NGO (Concern Worldwide, Save the Children and World Vision, respectively), and paid by the donor agencies who financed each project (Irish Aid, World Food Programme and DFID). Findings were disseminated through research reports, seminars and workshops, and "lesson learning" briefing papers intended to influence policy-makers (cf. Devereux 2008). However, these were not rigorous impact evaluations - not all had control 
groups, for instance-which made it impossible to attribute any positive changes observed, with confidence, to the project intervention alone.

As the number and scale of social protection programs grew, so did the size and sophistication of the evidence base. Randomized control trial (RCT) evaluations were commissioned that assessed prograe design and implementation features (e.g. targeting options) and impacts (e.g. on poverty reduction), using statistically significant sample sizes and multiround panel surveys (baseline, midline, endline) of treatment and control households. Donor agencies synthesized the findings of these evaluations in reports and books that were intended to advance thinking and promote best practice on social protection among external actors and especially among policy-makers in African countries. Seminal publications since 2010 include:

1. Cash Transfers Evidence Paper (Arnold et al. 2011), written by advisory staff in the Policy Division of the UK Department for International Development (DFID);

2. The Cash Dividend: The rise of cash transfer programs in Sub-Saharan Africa (Garcia and Moore 2012), a World Bank book written by an in-house economist and a consultant;

3. Cash Transfers: What does the evidence say? (Bastagli et al. 2016), a rigorous review commissioned by DFID from the Overseas Development Institute (ODI);

4. From Evidence to Action: The story of cash transfers and impact evaluation in sub-Saharan Africa (Davis et al. 2016), an edited book cofunded by the United Nations Food and Agriculture Organisation (FAO) and UNICEF.

"From Evidence to Action" is an output of the UN-funded Transfer Project, which commissioned evaluations of social cash transfer programs in eight countries: Ethiopia, Ghana, Kenya, Lesotho, Malawi, South Africa, Zambia and Zimbabwe. This was not independent academic research, it served an overt advocacy agenda. In their "Foreword", the Director-General of FAO and the Executive Director of UNICEF write: "These pages also document the ways in which the Transfer Project has influenced the policy debate in each of the eight countries ... FAO and 
UNICEF have long recognised the critical importance of working as strategic partners to strengthen the case for social protection" (Davis et al. 2016, 6).

\section{Building Capacity}

An important component of the effort to propagate social protection throughout Africa has been investment by external actors in building the capacity of policy-makers and practitioners from governments and agencies in understanding, designing and delivering social protection programs and systems. Capacity-strengthening has taken several forms, from study tours to training workshops to embedding expatriate technical advisors within government ministries. The justification given for this is technical—external actors are filling essential capacity gaps. "Poor country governments typically lack the technical, fiscal, management and logistical capacity to manage complex programmes effectively, hence the need for external support" (Holmes and Lwanga-Ntale 2012, 16).

But social protection is not simply a technocratic issue, it is ideologically inflected and different stakeholders have adopted very different positions, which also influence the direction that capacity building takes. Two of the leading providers of social protection advisory services- the World Bank and ILO_-also run their own training courses. Although the training offered by both agencies sounds very similar, the World Bank focuses on the "safety net" component of social protection, while the ILO favors a rights-based approach.

World Bank: From the early 2000s the World Bank ran an annual training course in Washington designed around its "social risk management" framework. This evolved into the "Social Safety Nets Core Course", a two-week course that "builds on the latest developments in safety nets as integral part of social protection systems, to provide participants with an in-depth understanding of the conceptual and practical issues involved in the development of social assistance or social safety net programs". The target audience is: "Policymakers and policy analysts from Government agencies, NGOs involved in the implementation of social safety nets, and 
operational staff from the World Bank and from bilateral and multilateral donor agencies." 1

ILO: The ILO runs a number of social protection training courses at its International Training Centre in Turin, Italy. The "Academy on Social Security" is a two-week course "on the governance, financing, reform and extension of social protection systems". The target audiences are "(1) managers, planners, advisers and professionals working in social security institutions, (2) policy-planners and officials from key ministries responsible for the development and monitoring of social protection systems, (3) representatives of the social partners involved in the governance of social security institutions and (4) practitioners and consultants of UN agencies working on social protection". ${ }^{2}$

An innovative donor-funded initiative that explicitly linked social protection evidence-building and capacity building to policy advocacy was the Regional Hunger and Vulnerability Programme (RHVP), which ran from 2005 to 2011 and was funded by DFID and the Australian Agency for International Development (AusAID). The ultimate indicator of RHVP's success was its impact on policy and practice in six countries: Lesotho, Malawi, Mozambique, Swaziland, Zambia and Zimbabwe. "RHVP wants to change mindsets, practice and policy to ensure that the chronic vulnerability that southern African countries are experiencing year on year is reduced." 3

RHVP linked evidence-building explicitly to policy advocacy: two of its "overlapping components" were "evidence gathering (the research component), and policy advice and advocacy (feeding new ideas into policy processes in country governments)" (Ellis et al. 2009, 10). Under its Regional Evidence-Building Agenda, RHVP commissioned case studies of 15 social protection programs (cash transfers, public works, school feeding, etc.) in the six countries, which were published in a book titled "Social Protection in Africa" (Ellis et al. 2009). RHVP focused its capacity building efforts on national and regional Vulnerability Assessment Committees (VACs), by strengthening staff capacities in data collection,

\footnotetext{
${ }^{1}$ www.worldbank.org/en/events/2016/04/25/safety-nets-core-course-2016.

${ }^{2}$ www.itcilo.org/en/areas-of-expertise/social-protection/academy-on-social-security.

${ }^{3}$ www.wahenga.net.
} 
analysis and reporting. Unusually, RHVP also engaged directly with parliamentarians, by running policy awareness workshops for the Southern African Development Community (SADC) Parliamentary Forum and sponsoring Members of Parliament to attend social protection training courses.

An assessment of RHVP's policy influence concluded that it had contributed to "significant increases in the level of attention and funding given to social protection by International Development Partners (IDPs), and improvements in the sophistication of their approach" (Jones 2011, 3). However, RHVP failed in two of its objectives: to establish a regional Centre of Excellence on social protection, and to transfer its website (wahenga.net) to a national institution or university. This arguably reflects not only limited technical capacity but also persistently shallow political commitment to social protection within the region. Once the impetus provided by external financing and expatriate technical support ended, so did the structures and activities that RHVP had instigated.

\section{Financial Support}

Many African governments were initially reluctant to introduce social protection programs, arguing that they are too expensive, especially if they involve regular (e.g. monthly) transfers of meaningful amounts of cash to all poor people (or all older persons, etc.) in the country on a long-term or permanent basis. External actors responded to the "unaffordability" argument in two ways.

First, donors and international financial institutions paid for social protection programs themselves, but with the expectation that governments would eventually take over the financing. This can be conceptualized as a "funding seesaw". External actors initially provide $100 \%$ of the funding needed for social assistance programs — as is the case with the top seven countries in Fig. 11.1, six of which are low-income economies. Over time a shift is expected to occur, away from external financing toward domestic financing. In the bottom six countries in Fig. 11.1, $100 \%$ of social assistance funding comes from the government. Five of these countries are middle-income economies and one (Seychelles) is a 


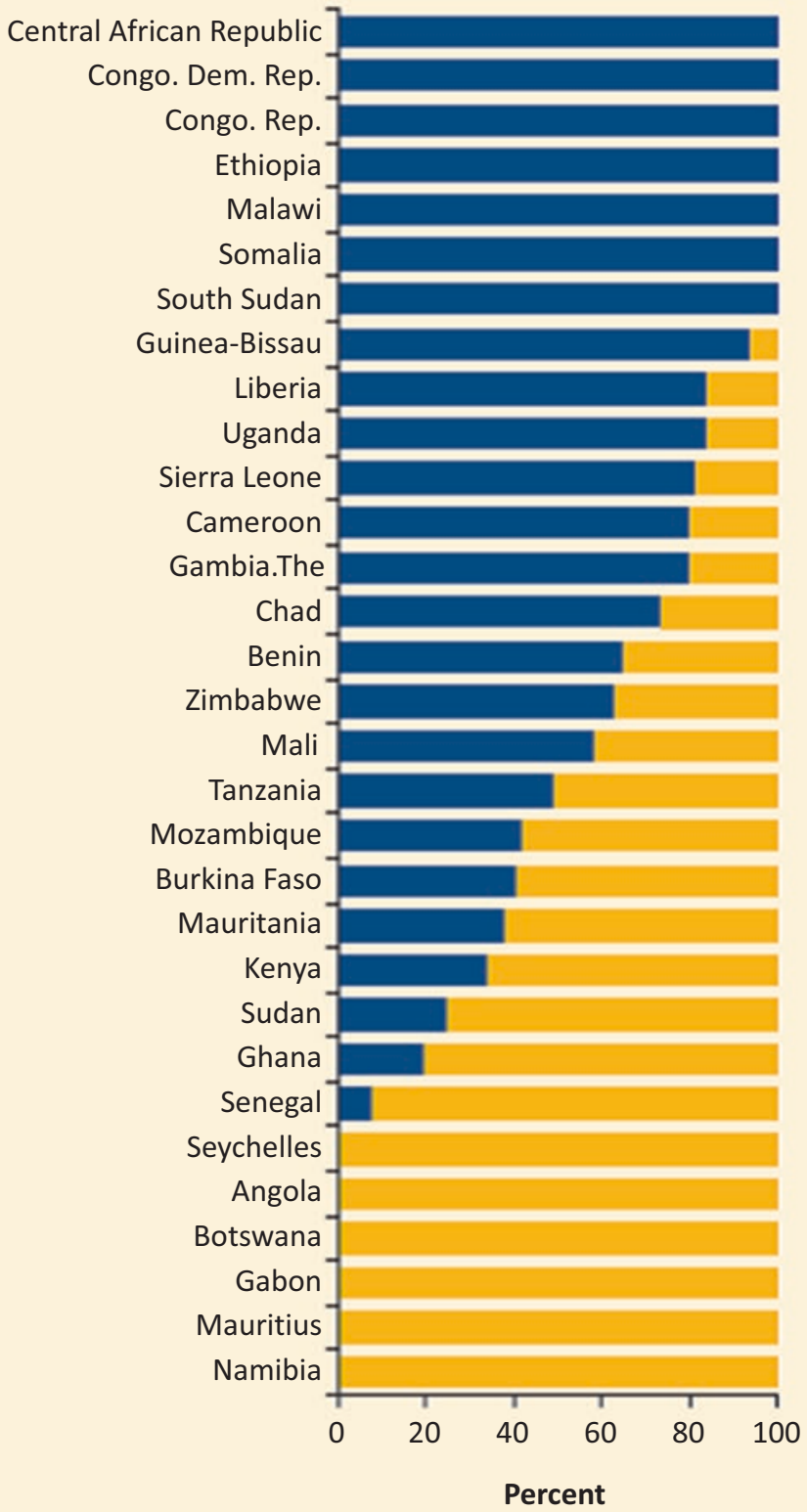

Donor-funded share Government share

Fig. 11.1 Share of governments and donors in social assistance funding in Africa. (Source: World Bank 2018, 18. Note: Social assistance programs include "unconditional and conditional cash transfers, noncontributory social pensions, food and in-kind transfers, school feeding programs, public works, and fee waivers" (World Bank 2018, 5)) 
high-income economy. ${ }^{4}$ This illustrates a familiar paradox, that countries with the greatest need for social protection have the least resources to deliver it.

Second, external actors tried to convince skeptical governments that they are wrong: social protection is affordable, even in low-income economies. According to ILO's World Social Protection Report 2017-19, spending on social protection as a percentage of GDP ranges from $4.5 \%$ in sub-Saharan Africa (with high variation within the region, from 0.1\% in Chad to over 7\% in Lesotho and Mauritius) to 18\% in Western Europe (peaking at 23\% in Finland and France) (ILO 2017). Although it might be expected that high-income economies have lower poverty rates and therefore less need for social protection, it could also be argued that poverty is low in these countries precisely because they spend more on redistributive measures that protect their citizens against falling into poverty.

This is also the basis of the "investment case" for social protection. External actors argue that social cash transfers to poor people builds their human capital by improving their nutrition, health, access to education and so on. This creates a virtuous cycle: poor children whose families receive social transfers have more chances of growing up and breaking the intergenerational transmission of poverty (see Chinyoka and Ulriksen, Chap. 10, this volume). Far from being wasteful public expenditure on consumption, by this reasoning social cash transfers can reduce poverty and stimulate economic growth (Barrientos and Scott 2008). This argument is favored by agencies, such as the World Bank, that see social protection as a poverty reduction instrument rather than as a human right.

Another argument often made against the fiscal unaffordability position is that spending decisions are political choices, not an inflexible technical rule. The ILO has identified several ways in which fiscal space for social protection can be increased, including:

1. reallocate public expenditures (e.g. remove fuel subsidies or cut defense spending);

2. increase tax revenues (e.g. earmarked taxes on tourism or financial transactions);

\footnotetext{
${ }^{4}$ https://datahelpdesk.worldbank.org/knowledgebase/articles/906519-world-bank-countryand-lending-groups.
} 
3. reduce illicit financial flows (which amount to more than ten times official development assistance globally);

4. borrow or restructure existing debt (e.g. renegotiate loans or apply for debt relief);

5. expand contributory social security coverage and revenue (e.g. incentivize participation of self-employed workers in formal social security schemes) (Ortiz et al. 2015).

Although examples can be found where governments have implemented these options - more often in Latin America and Asia than Africa (Ortiz et al. 2015)_-donors remain the main source of financing for social protection in most countries where the agenda has been introduced by external actors.

\section{Policy Support}

In the year 2000 not a single African country had a National Social Protection Policy (NSPP) or Strategy (NSPS). As recently as 2010, only five countries had promulgated their NSPP or NSPS. But in 2011, 5 more countries joined this group, doubling the total to 10, and by 2017 this number had trebled to 30, more than half of all African countries. Half of these are in West Africa $(n=15)$, the same as the combined total in Southern Africa $(n=6)$, Central Africa $(n=5)$, East Africa $(n=4)$ and North Africa $(n=0)$ (Devereux 2018). This is intriguing, because West Africa is often perceived as lagging behind East and Southern Africa in terms of social protection programming.

Some of Africa's oldest social protection programs are in Southern Africa—such as social pensions in South Africa (1928) (Seekings, Chap. 5, this volume) and Namibia (1949) - yet neither country has an NSPP or NSPS, nor does Botswana, which introduced a social pension more recently (1996). In West Africa, it appears that social protection policies have generally preceded programs, while in southern Africa, programs have preceded policies. This might be because the introduction of social protection in Southern Africa pre-dates the recent wave of donorsupported social protection, while in West Africa social protection poli- 
cies were developed with external support as part of a recent push by external actors to accelerate take-up of social protection in these "late adopter" countries. In South Africa, Namibia and Botswana, social protection programs have been well established for several decades, they are tax-financed and they receive very little technical or financial support from development agencies.

At first glance the proliferation of policies within the last decade might appear to endorse the view of social protection as a nationally owned process, but there are at least two reasons to question this interpretation. First, almost every African NSPP or NSPS draws inspiration from four conceptual frameworks, all products of the "Global North" rather than the "Global South". Second, most of these national strategy and policy documents were produced with substantial inputs from international consultants, who were commissioned by development agencies to perform this function on behalf of national governments.

The first conceptual framework for social protection was "Social Risk Management", devised around the turn of the century by the World Bank (Holzmann and Jørgensen 1999). Social Risk Management formalized the World Bank's view of social protection as an extension of "social safety nets" - a term they still prefer-and was extremely influential in the early 2000s, but was later superseded by more holistic approaches and is referenced in only two current African social protection policies.

Another early framework was the "Life-Cycle Approach", which was popularized by UNICEF and ILO (Garcia and Gruat 2003) and remains useful because it disaggregates social protection needs into age cohortspre-school, school-age children, youth, working-age adults and older persons-as well as cross-cutting categories such as persons with disability and pregnant and lactating women. The Life-Cycle Approach is the organizing framework for six African social protection policies.

In 2004 the UK Institute of Development Studies (IDS) proposed "Transformative Social Protection", which advocates for taking a social justice perspective (beyond managing livelihood shocks and life-cycle risks) by adding "transformative" measures such as anti-discrimination campaigns to the three foundation pillars of "protection" (social assistance), "prevention" (social insurance) and "promotion" (livelihood support) 
(Devereux and Sabates-Wheeler 2004). Transformative Social Protection is referenced by 12 social protection policies or strategies in Africa.

Most recently, the ILO formulated the "Social Protection Floor", a rights-based approach that argues for guaranteed access to essential health care and income security for all, throughout the life-cycle. (Note that the four conceptual frameworks overlap and complement each other, they are not mutually exclusive.) The Social Protection Floor was ratified by all member states of the International Labour Conference in 2012 (ILO 2012). To date the Social Protection Floor has been adopted by five African policies or strategies.

The fact that most African NSPP or NSPS documents favor imported models, instead of building on indigenous concepts of reciprocity and informal social support systems, reflects the reality that the recent wave of social protection policy formulation has been driven primarily by external actors rather than emerging out of context-specific domestic agendas. Many African social protection policy documents are facilitated or even drafted by expatriate experts, who are contracted by and represent the interests of the international development community. The "Acknowledgements" of Ghana's NSPP includes this paragraph:

The policy process benefited extensively from the technical and financial support of international partners. The Ministry particularly appreciates the collaboration with the United Nations Children's Fund (UNICEF), European Union (EU) and the World Bank in this exercise. Also, the analytical assistance received from the Economic Policy Research Institute (EPRI) from South Africa and the Socieux Team was of considerable benefit. The Ministry's gratitude is extended to United Nations Agencies, Bilateral Partners of Ghana and international and national nongovernmental organizations who contributed effective feedback and demonstrated continued interest in the policy. (Government of Ghana 2015, 4)

Some external actors even put their logo on the cover of the social protection policies and strategies they sponsored, alongside the national coat of arms. One example is The Gambia, which displays the logos of United Nations Development Programme (UNDP) and UNICEF on the cover of its National Social Protection Policy (NSPP). Another case is 
Liberia, which has the logos of UNICEF, EU, World Food Programme, World Bank, Japan International Cooperation Agency (JICA), African Development Fund and Concern Worldwide on the cover of its NSPP and NSPS.

Despite the impression this gives of unity among development partners, it is important to note that there are deep ideological divisions between them about the purpose and appropriate design of social protection. For example, because of its mandate, UNICEF supports child grants and pro-poor access to essential services such as education and health care. The World Bank promotes conditional cash transfers, which it perceives as an investment in human capital for long-term poverty reduction, and poverty targeting to maximize efficient use of scarce public resources. The ILO believes in a universal human right to social protection, and advocates for a guaranteed "social protection floor" for all. As seen below, some of these differences were played out in Zimbabwe. When external actors are divided about a policy agenda they are proposing to bankroll in a country, this further undermines the government's capacity to lead and own the process.

\section{External Actors and Social Protection in Zimbabwe ${ }^{5}$}

Although a fairly standard set of instruments has been introduced or promoted across Africa under the "new wave" of social protection post-2000, the impetus behind this policy process varied from country to country. In Ethiopia, for instance, large-scale social assistance in the form of the Productive Safety Net Programme (PSNP) was launched in 2005 as an antidote to persistent food insecurity and vulnerability to famine. In Lesotho and Swaziland, social pensions were introduced around the same

\footnotetext{
${ }^{5}$ This section draws on interviews conducted in Zimbabwe between 2016 and 2018 as part of $\mathrm{PhD}$ research (Kapingidza 2018). Officials from the government and external agencies were interviewed as key informants and focus group discussions were held with cash transfer beneficiaries. Participation was voluntary and informed consent was obtained. Names of research participants are not revealed, to uphold the principles of confidentiality and anonymity in research.
} 
time in response to HIV and AIDS, motivated by the recognition that older persons were assuming care responsibilities for large numbers of orphaned children. In other countries such as Zambia and Malawi, social cash transfers were piloted and later scaled up as a policy solution to chronic rural poverty. In Mozambique and Ghana, cash transfers are intended to address urban as well as rural poverty.

In Zimbabwe, the main driver for introducing new forms of social protection was the catastrophic economic collapse that peaked in the late 2000s. International development agencies played a leading role in promoting social protection as an instrument to fight rapidly rising levels of poverty and vulnerability. Donor influence was prominent in the establishment of the harmonised social cash transfer (HSCT) in 2011, which overshadowed existing interventions to become the flagship national social protection program, and in developing the National Social Protection Policy Framework (NSPPF) which was passed in 2016. Zimbabwe's development partners used "policy transfer" strategies they had developed elsewhere in Africa to drive the social protection agenda in Zimbabwe, including building evidence and capacity, and providing financial and policy support.

\section{Building Evidence}

A common strategy used by external actors to promote adoption of social protection by African governments was to run a small-scale pilot project, usually delivering cash transfers to poor people in a few rural communities, then commission an impact evaluation to demonstrate the project's effectiveness in improving beneficiaries' well-being, with the intention of persuading the government to implement the project at national scale. The same strategy was pursued in Zimbabwe. ${ }^{6}$ Given the fact that social cash transfers were initiated relatively late in Zimbabwe,

\footnotetext{
${ }^{6}$ Significantly, a chapter on Zimbabwe in 'From Evidence to Action' (Davis et al. 2016), the FAO/ UNICEF book on cash transfer impact evaluations mentioned earlier, is subtitled 'Using evidence to overcome political and economic challenges to starting a national unconditional cash transfer programme' (Seidenfeld et al. 2016).
} 
learning and evidence generated in other African countries was available. Documentation of experiences, impacts and best practices in Kenya, Zambia and elsewhere was shared with the Ministry of Labour and Social Services (MoLSS).?

Apparently convinced by the evidence from other countries that cash transfers "work", the MoLSS requested the donors to commit to funding a full-scale national cash transfer program, but they refused, arguing that they needed to test the model in Zimbabwe first. " "Team Consult", led by Bernd Schubert (a German consultant who had earlier led the establishment of similar social cash transfer pilot projects in Mozambique, Zambia and Malawi) was contracted to support the Department of Social Services to "design a national government owned and coordinated cash transfer programme which targeted food poor and labour constrained households" (Schubert 2010, 8). Team Consult was recruited by the MoLSS but paid by UNICEF, which allowed UNICEF to play an oversight role over the process. This had implications for ownership of the process.

Starting with a pilot of just 111 households in Goromonzi district in Mashonaland East province in 2011, cash transfers were rolled out to about 19,000 households in 10 districts in 2012 (MoLSS and UNICEF 2012), extending to 16 districts in 2013 and 20 districts (2 per province) in 2014 (see Table 11.1). A positive initial evaluation of the HSCT led by Bernd Schubert, who was again hired by UNICEF (Schubert 2011), prompted an expansion in coverage and further evaluations. Leading research institutes, the American Institutes of Research and the University of North Carolina at Chapel Hill, in partnership with the University of Zimbabwe's Centre for Applied Social Sciences, were contracted by

Table 11.1 Coverage of the HSCT program in Zimbabwe, 2011-2017

\begin{tabular}{|c|c|c|c|c|c|c|c|}
\hline Year & 2011 & 2012 & 2013 & 2014 & 2015 & 2016 & 2017 \\
\hline sen & 111 & 18,940 & 3,200 & 55,509 & 55,509 & 23,000 & 23,000 \\
\hline Districts & 1 & 10 & 16 & 20 & 20 & 8 & 8 \\
\hline
\end{tabular}

Source: Kapingidza (2018), compiled from MPSLSW and donor official 2

\footnotetext{
${ }^{7}$ Interview with government official \#2.

${ }^{8}$ Interview with government official \#3.
} 
UNICEF to evaluate the program. Funding came from United Nations agencies (UNICEF, FAO), a multilateral agency (EU) and European bilateral agencies (DFID, Kingdom of the Netherlands, Swedish International Development Cooperation Agency [SIDA] and Swiss Agency for Development and Cooperation [SDC]). The 2014 and 2017 evaluation reports (AIR 2014; UNC 2017) generally registered positive impacts of the HSCT.

However, despite this evidence of the feasibility and effectiveness of cash transfers, the Government of Zimbabwe has been consistently reluctant to take over full responsibility for funding the HSCT, despite its desire, as expressed in the Zimbabwe Agenda for Sustainable SocioEconomic Transformation (ZimAsset), ${ }^{9}$ to reach a target of 100,000 households by 2015 and 200,000 by 2018 (UNCT and GoZ 2014). Coverage actually peaked in 2014 and 2015, when the HSCT paid cash to 55,509 households (Table 11.1), 10\% of the national total of 539,000 households, in 20 of Zimbabwe's 59 districts (UNCT and GoZ 2014).

\section{Building Capacity}

In Zimbabwe, as elsewhere, strategic investment in capacity-strengthening became a vehicle for external actors to ensure that they channeled technical assistance toward their preferred programs and policies. Thus, technical support to the Ministry of Public Service, Labour and Social Welfare (MPSLSW) ${ }^{10}$ was intended to influence adoption of the HSCT. Capacity building involved the international agencies sponsoring government staff to attend training on social protection, both within the country and abroad. Some MPSLSW officials were funded to participate in courses at the ILO's International Training Centre in Italy (discussed above), to build their theoretical comprehension of social protection and their technical capacity to implement social cash transfers. ${ }^{11}$

\footnotetext{
${ }^{9} \mathrm{ZimAsset}$ is the national economic strategy for 2013-2018.

${ }^{10}$ The MoLSS reverted to its former name of MPSLSW after the end of the Government of National Unity (GNU) in 2013.

${ }^{11}$ Interview with government official \#3.
} 
Another capacity-strengthening strategy applied by UNICEF and other agencies was to establish a Coordination Unit for the HSCT within the Department of Social Welfare in the Ministry of Labour and Social Services. The Unit was funded through donor resources. It played a secretariat role but it also monitored implementation of the HSCT. "They were actually in charge of running that programme although there were other officers within the ministry who were seconded, overseeing also what was going on for capacity resource transfer, so that when this Unit leaves the programme sails on smoothly." 12

While donors claim that the ministry now runs the HSCT, since the Coordination Unit was disbanded in 2014, the ministry's role is limited by the fact that approximately $90 \%$ of funding still comes from donors and the program has been drastically downscaled due to donor fatigue (see Table 11.1). Given the support it received from the donors, the Unit became envied as it was better resourced than other departments in the ministry. Anderson and Therkildsen $(2007,9)$ note that "parallel administrative systems to handle the implementation of donor supported activities_-such as donor controlled management units-undermine ownership". The Unit did strengthen administrative capacity to deliver the HSCT, but it did not create much government ownership.

\section{Financial Support}

The evolution of the HSCT and the development of the NSPPF reflect how external actors have used their financial leverage to influence the social protection agenda in Zimbabwe. At inception, the HSCT was $100 \%$ donor-funded and to date the program is still almost totally dependent on external funding. ${ }^{13}$ The setting up of the HSCT does not reflect genuine local ownership and broad participation. The program was initiated and funded by donors and established in parallel to government-run national programs like the Basic Education Assistance Module (BEAM) and Public Assistance. MoLSS only provided implementation structures

\footnotetext{
${ }^{12}$ Interview with a former government official.

${ }^{13}$ Interview with donor official \#1.
} 
for the HSCT, while external agencies' funding of the program gave them unprecedented power to play an influencing and oversight role.

Financing decisions provide an unequivocal indication of strategic interests and priorities. As in other African countries, donors in Zimbabwe have consistently shown more interest in supporting social cash transfers than other forms of social protection. Conversely, financial commitment from the government is negligible, violating an agreement with development partners to co-fund the HSCT on a 50:50 basis. "The government never fulfils its mandate to fund $50 \%$ of HSCT according to what we agreed." 14 The Child Protection Fund (CPF), administered by UNICEF, is the funding mechanism for the HSCT from the donors' side. DFID is the major donor and contributes $75 \%$ of the total cost. ${ }^{15}$ In its first phase, DFID, EU, Netherlands, SDC and SIDA co-funded the HSCT. However, the Netherlands and the EU pulled out during the first phase.

Because donors do not fund the government directly, a private security company called Securico collects the money from UNICEF and disburses it to the communities for payment; the ministry only witnesses the payment. ${ }^{16}$ Deloitte and Touche initially did auditing until UNICEF persuaded the donors to opt for government auditors, ${ }^{17}$ because the use of private security and private auditing firms is expensive and does not build government capacity.

Phase II of the HSCT (June 2016-May 2019) faced a massive decline in external funding that was compounded by the ongoing lack of disbursement of funds from the government. DFID, the largest funder of the HSCT since its inception, halved its funding to $£ 20$ million, from $£ 38$ million in Phase I. Donor frustration over government's lack of commitment to take over funding of HSCT largely explains this downscaling of donor support. This reflects the dangers of heavy reliance on external funding. No program can be sustained indefinitely by donors, as they are accountable to their own constituencies and their priorities are constantly shifting between programs, sectors and countries.

\footnotetext{
${ }^{14}$ Interview with donor official \#1.

${ }^{15}$ Interview with donor official \#2.

${ }^{16}$ Interview with government official \#3.

${ }^{17}$ Interview with donor official \#3.
} 
Phase II of the HSCT therefore has a more limited scale. Only 23,000 households have been reached in the current phase, as compared to 55,000 households targeted in the last years of Phase I. Geographically, the number of districts covered have been reduced from 20 to 8 (see Table 11.1). Beneficiaries in districts that have been dropped from the program were not aware that their benefits were about to be abruptly stopped, because the government did not communicate this to them. ${ }^{18}$ Moreover, funding prospects for the HSCT beyond 2019 are uncertain.

Donors also funded the development of the NSPPF from the beginning to its launch, in a process that fell far short of government or national ownership. "Ownership implies that the recipient government's political objectives dominate the development agenda, and that transparent local political decisions are made based on broad involvement and participation of local stakeholders. This requires that government, parliament and other political institutions make decisions about policy and resource allocation serviced and advised by the civil service without distorting donor interference" (Anderson and Therkildsen 2007, 9).

The process of developing the NSPPF was supported by the World Bank, UNICEF, DFID, ILO, FAO, UNDP and all members of the Organisation for Economic Co-operation and Development (OECD) CPF donor group (GoZ 2016). The World Bank funded the first draft and when their funding ended, UNICEF came on board and funded the process until the cabinet approved the policy. ${ }^{19}$ The government did not contribute to the costs of policy development. The dominance of development partners in social protection financing is illustrated in Fig. 11.2.

\section{Policy Support}

The idea of developing a national social protection policy framework for Zimbabwe was first mooted by UNDP in 2009, but momentum only accelerated from 2014. ${ }^{20}$ There was a realization within government and development partners that the lack of a policy made it difficult to

\footnotetext{
${ }^{18}$ Interview with donor official \#2.

${ }^{19}$ Interview with government official \#3.

${ }^{20}$ Interview with government official \#1.
} 


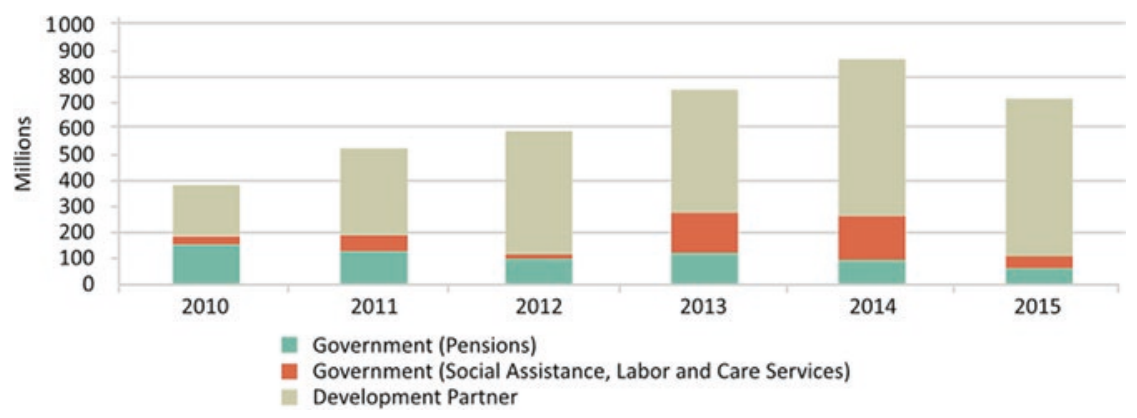

Fig. 11.2 Sources of financing for social protection in Zimbabwe, 2010 to 2015. (Source: Government of Zimbabwe and World Bank 2016, 15)

coordinate social protection activities. According to a former government official, "In the absence of an overall policy framework, social protection remains ad hoc, piecemeal and of little impact, if any. Harmonisation and coordination are virtually not feasible." ${ }^{21}$ National development strategies, including ZimAsset, lamented the lack of a social protection policy. ${ }^{22}$ Although a number of relevant policy instruments were in place, notably the Social Transfer Policy Framework, the Basic Education Assistance Module Manual and Public Works Guidelines, those tools and related programs remained isolated and loosely coordinated. ${ }^{23}$

The need for a policy became more urgent after the HSCT program was launched in 2012. "We realised there were other social protection issues that were not covered by the cash transfer programme. So the push for the NSPPF became vocal again as stakeholders desired to finalise the policy document. So UNICEF brought resources to finalise the policy." ${ }^{24}$

The policy framework was eventually approved by the Cabinet in November 2016 and launched in December 2016. However, the process was overly dependent on external funding and for this reason it stopped and started multiple times, whenever an external agency ran out of funds or interest, until another interested external agency stepped up to take

\footnotetext{
${ }^{21}$ Interview with a former government official.

${ }^{22}$ Interview with government official \#2.

${ }^{23}$ Interview with government official \#3.

${ }^{24}$ Interview with government official \#3.
} 
the lead. After 2009, UNDP "disappeared from the agenda and we got stuck for a while. Later on UNICEF came on board but disappeared again. When UNICEF reappeared later they never stopped and have been at the forefront until today." 25

The government failed to commit any funds to the policy formulation exercise, so external actors drove the process by virtue of being the funders. Consequently, the Government could not control what it did not fund and only played a facilitatory role. Overall, the process was never smooth within the government itself, between the government and external agencies, or between the agencies themselves, as different interests took center stage.

Inter-agency politics also affected the process, as UNICEF tried to advance its own agenda while also needing to incorporate other agencies' interests. A number of bilateral and multilateral agencies were jockeying for influence. While they were generally comfortable with the role played by UNICEF in managing CPF and providing technical assistance to the government, they had different agendas and approaches. For example, the ILO wanted to accelerate the policy process, whereas the UNICEF favored a more consultative and inclusive approach.

I remember arguing with colleagues in ILO who were pushing the process to be very fast but we said no, we want a national dialogue based process where we try as much as possible to ensure that we involve a wider spectrum of people. At each stage you could get people who would say they were never involved, so we would take time to get their input and assure them that it was never too late. So the process itself was quite long. ${ }^{26}$

There was also tension between UNICEF and the World Bank, which pushed hard for conditional cash transfers, which UNICEF does not believe in, partly because imposing conditionalities violates the human right to social protection.

\footnotetext{
${ }^{25}$ Interview with government official \#1.

${ }^{26}$ Interview with donor official \#3.
} 
We were quite strategic. When we started to push government we quickly put in resources and brought everyone to the table. I think we played the politics right. We actually requested the World Bank to second a consultant to the team developing the policy just to manage the political dynamics, but it was clear that they were not the drivers of the process. We made sure that the government was in the driving seat, and we provided a lot of backstopping to ensure that they were the ones in charge. We did not get swayed into the World Bank's thinking on social protection. Their thinking on cash transfers has always been conditional. ${ }^{27}$

UNICEF used the "soft power" conferred by its position as the leading funder of the NSPPF to take control of the policy process, and to resist attempts by other stakeholders to pull the policy in different directions. The policy space became a battlefield for external actors led by UNICEF, the World Bank and ILO, as each tried to impose their ideas on how best to program social protection in Zimbabwe. Given this reality, the claim by development partners that the government drove the process is disingenuous.

Due to the leading role of UNICEF and its strategic management of the politics of the policy process, it is hardly surprising that the content of the final NSPPF document reflects UNICEF's influence. The NSPPF adopts three approaches to social protection:

1. Social protection as a human right. social protection is an entitlement that the State has an obligation to provide as enshrined in international conventions;

2. Systems approach to social protection: poor and vulnerable people are heterogeneous and have different forms of vulnerabilities that require different types of support; and

3. Multi-sectoral approach to socialprotection: a holistic approach is needed that makes cross-sectoral linkages and is anchored in a life-cycle approach, to enhance coordination and harmonisation (Government of Zimbabwe 2016, 24-25).

\footnotetext{
${ }^{27}$ Interview with donor official \#3.
} 
These three guiding principles mirror UNICEF's Global Social Protection Strategic Framework, which takes a human rights approach, aims to support the development of nationally owned integrated social protection systems that are grounded in a multi-sectoral approach, and uses the life-cycle approach to disaggregate vulnerabilities and social protection needs (UNICEF 2012).

\section{External Influence and the National Context}

The Zimbabwean case is unusual in the sense that the social protection policy process was introduced by external actors during a period of significant political and socioeconomic uncertainty. The collapse of the Zimbabwean economy, with GDP falling by more than $40 \%$ between 2000 and 2008, when inflation reached an unprecedented 500 billion percent (World Bank 2011), resulted in poverty and unemployment rates of $72 \%$ and $80 \%$ respectively (World Bank 2014). Western governments imposed sanctions against Zimbabwe in the early 2000s over the "fast track land reform" program and, consequently, international bilateral engagements ceased (Seidenfeld et al. 2016). Outstanding arrears to international financial institutions further complicated the crisis, as Zimbabwe could not qualify for a bail-out.

However, after the formation of the Government of National Unity (GNU) in 2009, western governments and development agencies, led by the British, reached a "common consent" with the Government of Zimbabwe to initiate the HSCT program. The international community had a positive perception of GNU, which reflected a compromise between President Mugabe's Zimbabwe African National Union-Patriotic Front (ZANU-PF) and the opposition Movement for Democratic Change (MDC). Significantly, the Minister of Labour and Social Services in the GNU was a member of the MDC, which was more appealing to the international community than ZANU-PF. Upon her appointment to the Ministry of Labour and Social Services (MoLSS) in 2009, "everything had gone down, there was nothing at Pensions and it was difficult to say 
there was a social protection system in place except a few haphazard interventions". ${ }^{28}$ She presided over the inception of the HSCT and its implementation until the GNU ended in 2013. Initiatives to develop a national social protection policy also started during the GNU.

Indeed, the recovery in the social sectors during the GNU period is owed to donor support that culminated in multi-donor funding mechanisms like the Child Protection Fund (CPF), Education Transition Fund (ETF) and The Health Transition Fund (HTF). UNICEF managed these three funds as the political context (sanctions and debt arrears) only permitted donors to fund interventions through the United Nations family.

Why donors are not funding Government directly is a political issue. Relations with the West are frozen and the money is coming from the West. So donors are more comfortable supporting government programmes but not giving government the money. Even when we have the money we have restrictions insofar as what money can be channelled through government systems. ${ }^{29}$

The political context is unique in the sense that the external actors supported the development of the social protection policy and the HSCT through UNICEF, instead of through budget support to the government. This is contrary to other countries like Zambia and Kenya (see Künzler, Chap. 4, this volume), where direct donor financing of social protection through the government yielded more political buy-in, as evidenced by significant expansion of cash transfers coverage and increasing funding from the government. The attempt to persuade the government of Zimbabwe to adopt the HSCT as the flagship social protection intervention to replace existing safety net programs reflects similar experiences in other African countries, as does the influential role played by UNICEF, DFID, ILO and World Bank-four of the leading global agencies working on social protection in Africa.

\footnotetext{
${ }^{28}$ Interview with a former cabinet minister.

${ }^{29}$ Interview with government official \#3.
} 


\section{Conclusions}

The rapid rise of social protection as a development policy agenda in Africa, as reflected in the ever increasing numbers of strategies, programs and poor or vulnerable people reached by social cash transfers and related interventions, can be seen as a success story for African governments who have adopted and implemented these ideas. But it is equally a success story for the external actors who have driven this agenda energetically across Africa, with substantial investments of financial resources and technical expertise, for the past two decades. Using an array of instruments of "soft power", the international development community has cajoled and supported African governments to introduce and scale up cash transfer projects, to formulate and promulgate national social protection policies or strategies and to build increasingly complex social protection systems.

Reflecting on the Zimbabwean experience, which in many respects mirrors that of other African countries, allows us to identify several indicators of the extent to which a social protection policy process can be characterized as "donor-driven" rather than "nationally owned". These indicators include:

1. whether the policy process is conceived, designed and facilitated mainly by external actors through their advisors and consultants, or is truly led by government policy-makers and officials;

2. whether consultation processes are tokenistic and dominated by elites, or wide-ranging and genuinely inclusive of grassroots organizations and poor people (i.e. prospective beneficiaries);

3. whether external actors favor specific instruments (e.g. SCT) rather than other instruments that may be favored by African governments (e.g. agricultural input subsidies);

4. if a donor-supported pilot project becomes a flagship national program, to the detriment of existing national programs that do not receive donor support; 
5. whether evaluations of social protection programs are commissioned by external actors and conducted by international research institutes, or commissioned by the government and conducted by local researchers;

6. the proportion of social protection spending that is financed by external actors, versus domestic resource mobilization and government commitment to co-financing that is actually disbursed.

Social protection in Zimbabwe fails the test of national ownership on all six criteria. The Zimbabwean case illustrates the influential role of external actors in the social protection policy transfer process. In particular, it reveals how development partners working in African countries are political actors who use their financial leverage and technical expertise to advance their interests in the social protection agenda, while claiming neutrality and presenting their policy advice as being grounded in technical analysis and empirical evidence. Ultimately, institutionalizing social protection in African countries is not a consensus-building exercise, but a contestation and negotiation among a range of development partners-each of which strives to impose its preferred approach on the policy process - as well as between these external actors and the national government.

The story of social protection in Zimbabwe to date is instructive. Although the international actors deployed the strategies they had applied successfully in several other African countries to induce the adoption of cash transfer programs, these strategies appear to have failed in Zimbabwe, because the process of its introduction was flawed. One clear implication, for Zimbabwe and elsewhere, is that negotiations between national governments and international actors about which policies and processes international actors support in a country must be based on genuine consensus-building about policy priorities, agreed modalities, realistic timelines and division of responsibilities in terms of financing and implementation. Otherwise there is a real risk, as the Zimbabwe case reveals, of social protection programs being introduced and then withdrawn, and the biggest losers from a failed social protection policy process are those who were supposed to benefit-the poor and vulnerable. 


\section{References}

American Institutes for Research. 2014. 12-Month Impact Report for Zimbabwe's Harmonised Social Cash Transfer Programmes. Washington, DC: AIR. Anderson, Ole, and Ole Therkildsen. 2007. Harmonisation and Alignment: The Double-Edged Swords of Budgetary Support and Decentralised Aid Administration. DIIS Working Paper 4, Copenhagen: Danish Institute for International Studies (DIIS).

Arnold, Catherine, Tim Conway, and Matthew Greenslade. 2011. Cash Transfers Evidence Paper. London: DFID.

Barrientos, Armando, and James Scott. 2008. Social Transfers and Growth: A Review. BWPI Working Paper 52, Manchester: Brooks World Poverty Institute.

Bastagli, Francesca, Jessica Hagen-Zanker, Luke Harman, Valentina Barca, Georgina Sturge, and Tanja Schmidt, with Luca Pellerano. 2016. Cash Transfers: What Does The Evidence Say? A Rigorous Review of Programme Impact and of the Role of Design and Implementation Features. London: ODI.

Davis, Benjamin, Sudhanshu Handa, Nicola Hypher, Natalia Winder Wossi, Paul Winters, and Jennifer Yablonski, eds. 2016. From Evidence to Action: The Story of Cash Transfers and Impact Evaluation in Sub-Saharan Africa. Oxford: Oxford University Press.

Devereux, Stephen. 2008. Innovations in the Design and Delivery of Social Transfers: Lessons Learned from Malawi. Concern Worldwide Policy Paper, London: Concern Worldwide.

2018. The rise and rise of social protection in Africa. Keynote speech at the international workshop: Building Social Protection Systems in the Global South: Different Trajectories and the Influence of External Factors. Bremen: University of Bremen.

Devereux, Stephen, and Rachel Sabates-Wheeler. 2004. Transformative Social Protection. In IDS Working Paper 232. Brighton: Institute of Development Studies.

Ellis, Frank, Stephen Devereux, and Philip White. 2009. Social Protection in Africa. Cheltenham: Edward Elgar.

Garcia, A. Bonilla, and J.V. Gruat. 2003. Social Protection: A Life-Cycle Continuum Investment for Social Justice, Poverty Reduction and Sustainable Development. Geneva: International Labour Office.

Garcia, M., and C. Moore. 2012. The Cash Divided: The Rise of Cash Transfer Programs in Sub-Saharan Africa. Washington, DC: World Bank.

Government of Ghana. 2015. Ghana National Social Protection Policy. Accra: Ministry of Gender, Children and Social Protection. 
Government of Zimbabwe. 2016. National Social Protection Policy Framework for Zimbabwe. Harare: Government of Zimbabwe.

Government of Zimbabwe and World Bank. 2016. Zimbabwe Public Expenditure Review: Volume 5 Social Protection. Harare: Government of Zimbabwe and World Bank.

Holmes, Rebecca, and Charles Lwanga-Ntale. 2012. Social Protection in Africa: Review of Social Protection Issues in Research. PASGR Scoping Study, Nairobi: Partnership for African Social and Governance Research (PASGR).

Holzmann, Robert, and Steen Lau Jørgensen. 1999. Social Risk Management: A New Conceptual Framework for Social Protection and Beyond. Social Protection Discussion Paper 6. Washington DC: World Bank.

ILO. 2012. Text of the Recommendation Concerning National Floors of Social Protection. Geneva: International Labour Conference.

International Labour Office. 2017. World Social Protection Report 2017-19. Geneva: ILO.

Jones, Harry. 2011. Learning Lessons from the Policy Influence of the Regional Hunger and Vulnerability Programme (RHVP). London: Overseas Development Institute (ODI).

Kapingidza, Samuel. 2018. The Political Economy of Social Protection in SubSaharan Africa: Tracing the Agenda in Zambia and Zimbabwe. PhD Thesis, University of the Western Cape, Cape Town.

Kuss, Maria Klara. 2015. The Prospects and Politics of Social Protection Reform in Zambia. IDS Working Paper 453, Brighton: Institute of Development Studies.

Ministry of Community Development and Social Services and German Technical Cooperation. 2007. Final Evaluation Report: Kalomo Social Cash Transfer Scheme. Lusaka: MCDSS.

Ministry of Labour and Social Services and UNICEF. 2012. Manual of Operations for the Zimbabwe Harmonised Social Cash Transfer Programme. Harare: MoLSS and UNICEF.

Ortiz, Isabel, Matthew Cummins, and Kalaivani Karunanethy. 2015. Fiscal Space for Social Protection: Options to Expand Social Investments in 187 Countries. Extension of Social Security (ESS). Working Paper 48. Geneva: International Labour Office.

Pruce, Kate, and Sam Hickey. 2017. The Politics of Promoting Social Protection in Zambia. Effective States and Inclusive Development (ESID). Working Paper 75. Manchester: University of Manchester.

Schubert, Bernd. 2010. Child-Sensitive Social Protection in Zimbabwe. Harare: UNICEF.

2011. Lessons Learned from Ongoing Social Cash Transfer Programmes in Zimbabwe. Harare: UNICEF. 
Seidenfeld, David, Lovemore Dumba, Sudhanshu Handa, Leon Muwoni, Hannah Reeves, and Elayn Sammon. 2016. Zimbabwe: Using Evidence to Overcome Political and Economic Challenges to Starting a National Unconditional Cash Transfer Programme. In From Evidence to Action: The Story of Cash Transfers and Impact Evaluation in Sub-Saharan Africa, ed. Benjamin Davis, Sudhanshu Handa, Nicola Hypher, Natalia Winder Rossi, Paul Winters, and Jennifer Yablonski. Oxford: FAO, UNICEF and Oxford University Press.

UNICEF. 2012. Integrated Social Protection Systems: Enhancing Equity for Children. UNICEF Social Protection Strategic Framework. New York: UNICEF. United Nations Country Team and Government of Zimbabwe. 2014. Country Analysis Report. Harare: UNCT and GoZ.

University of North Carolina at Chapel Hill. 2017. Zimbabwe's Harmonised

Social Cash Transfer Programme: Endline Impact Evaluation Report. North Carolina: UNC.

World Bank. 2011. Challenges in Financing Education, Health, and Social Protection Expenditures in Zimbabwe. Zimbabwe - Public Expenditure Notes (Vol. 3). Washington, DC: World Bank.

- 2014. Republic of Zimbabwe Economic Policy Dialogue: Policy Notes for the New Government - 2013. Report No: ACS13915. Washington, DC: World Bank. - 2018. The State of Social Safety Nets 2018. Washington, DC: World Bank.

Open Access This chapter is licensed under the terms of the Creative Commons Attribution 4.0 International License (http://creativecommons.org/licenses/ by/4.0/), which permits use, sharing, adaptation, distribution and reproduction in any medium or format, as long as you give appropriate credit to the original author(s) and the source, provide a link to the Creative Commons licence and indicate if changes were made.

The images or other third party material in this chapter are included in the chapter's Creative Commons licence, unless indicated otherwise in a credit line to the material. If material is not included in the chapter's Creative Commons licence and your intended use is not permitted by statutory regulation or exceeds the permitted use, you will need to obtain permission directly from the copyright holder.

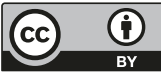

